of aluminium accumulation, as measured by changes in serum aluminium concentration, was haemodialysis using dialysate fluid prepared from softened mains water (mean aluminium concentration $1.47 \mu \mathrm{mol} / 1$, range $0.3-3.7 \mu \mathrm{mol} / \mathrm{l}$ ). This practice is still common in many intensive care units. We do not, nor did we, dispute that the regular administration of albumin solutions contaminated with aluminium will result in aluminium accumulation, an effect most pronounced in patients with chronic impairment of renal function.

Dr Maharaj and colleagues themselves presented some anomalies: their third patient, who had been exposed to $5707 \mu \mathrm{mol}$ of aluminium over seven years, achieved a serum aluminium of 14.4 $\mu \mathrm{mol} / 148$ hours after a desferrioxamine challenge whereas their second patient, who had been exposed to $885 \mu \mathrm{mol}$ of aluminium over six months, had a value of $3.6 \mu \mathrm{mol} / \mathrm{l}$, yet both patients were quoted as having similar bone aluminium content on biopsy and a similar degree of renal impairment. These data suggest that desferrioxamine may remove aluminium from other body tissues as well as from bone.

In three patients who presented with acute renal failure and subsequently developed life threatening septicaemia we observed considerable increases in the serum aluminium concentration, from a mean of $0.96 \mu \mathrm{mol} / 1$ (range $0.7-1.2 \mu \mathrm{mol} / 1$ ) to a mean of $6.2 \mu \mathrm{mol} / /$ (range 3.5-7.6 $\mu \mathrm{mol} / \mathrm{l}$ ). Subsequent histochemical analysis of iliac bone specimens at necropsy failed to show any aluminium, even though these patients had undergone haemodialysis with softened mains water (the mean number of dialysis treatments was 16.3 (range 13-20)) and had been given infusions of human albumin solution known to be contaminated with aluminium (mean amount of albumin solution given 21.5 litres (range 12:3-34-3)). To account for the increases observed aluminium must have been stored in tissues other than bone.

Obviously aluminium accumulation will occur over long periods in bone and other body tissues in patients who are exposed to high aluminium concentrations, the accumulation being greater in those with renal impairment; but the extent of the accumulation—and here we agree with Dr Maharaj and colleagues-cannot be accurately predicted by serum aluminium measurements alone.

N B ROBERTS A DAVENPORT

Royal Liverpool Hospital Liverpool L7 8XP

1 Davenport A, Roberts NB. Serum aluminium levels in acute renal failure. Lancet 1986;ii:1397-8.

\section{Why sports injury clinics?}

SIR,-Mr P G Stableforth raises several important issues about providing sports injury services to the community (3 October, p 799).

An appreciable proportion of attendances at hospital accident departments, particularly at weekends, result from acute musculcskeletal injuries caused by sport. The numbers stretch the resources of junior emergency staff to a level at which their primary concern is to define whether (using conventional orthopaedic priorities) an injury requires referral to a fracture clinic. Patients with overuse injuries peculiar to sport also present to general practitioners, whose difficulties are often due to a lack of knowledge of biomechanics and techniques related to particular sports; decision making and advice in consequence become arbitary.

The only satisfactory remedy ultimately lies in an improved level of tuition in musculoskeletal examination techniques for medical students and an improved level of postgraduate education in recognising and managing soft tissue injuries. Such training would allow the doctor of first contact-the general practitioner and traumatologist-to cope adequately with most of the problems (however and wherever occurred) as part of primary health care. The future generalist sports physician must inevitably come therefore from the ranks of general practice, and orthopaedic (physical) medical teaching needs to be an obligatory part of the general practitioners' vocational training scheme. Appropriate postgraduate education in sports medicine would then lead to the establishment of a satisfactory career structure for doctors in this specialty. With some two million sports injuries occurring every year this may well be inevitable.

Regrettably, there continues to be a body of opinion within the medical profession which considers sports injuries as self imposed and therefore deserving of private treatment only. Soft tissue trauma, however, may give rise to as much morbidity and loss of time from work as fractures, which have historically been accorded priority in orthopaedic practice. There is no point in attempting to gloss over the absence of fundamenta training, but first there needs to be a radical revision of medical opinion in line with rising consumer demand in favour of accepting the need for the development of orthopaedic and sports medicine within the general framework of medicine in the United Kingdom.

Michael Hutson

Institute of Sports Medicine,

London Bridge Hospital,

London SE1 2PR

\section{Should medical students go to South Africa?}

SIR,-The tragic divisions that exist within South Africa over how to end apartheid and bring in a jus and free society there reach us continually over here.

Thus it is that two medical students-Helen Gray (5 September, p 348) and Tom Coffey (26 September, p 781) - arrive at completely opposite conclusions about working in South Africa. Both probably exaggerate-for good or ill-the effects of a student elective on the future of that unhappy land. But none can miss the passion through which each comes to the conclusion to go there or to stay away.

It is a sad but unavoidable truth that we humans disagree only when we are talking about the same thing. The wish of both parties is for the same justice, the same peace. Yet their responses are totally opposed. It is exactly so, though with far more serious consequences, between the prophetic Archbishop Tutu and the more pragmatic Chief Buthelezi.

Recently, we spent six months working in the casualty department of the health clinic in Alexandra, a black suburb of Johannesburg. This was a calculated response to an invitation. We went knowing that we must offend some who believe that only absolute isolation can bring about change in South Africa. While we were there we met both Archbishop Tutu and Chief Buthelezi. From both we seemed to receive absolution for our conduct, since what we did was of apparent benefit to thei suffering people.

Now we hear Oliver Tambo, from the headquarters of the African National Congress, reminding his people - and all of us - that South Africa must be looking at "the alternatives," must prepare the nation for the time when the people are free and the old tyrannies done away with. To this end, the African National Congress has instructed the young to go back to school after three years of boycott.

Is it not time for us in Britain also to begin to look at "the alternatives" and actively embrace this reconstructive process? We are not in medicine to keep our political noses clean but to hear the shout of pain. There is no right way to go, and no wrong way either. We have only our humanity to guide us, and our age old professional discipline.

ANTHONY BARKER

London MARGARET BARKER

SIR,-Driving $900 \mathrm{~km}$ every month to visit exmission hospitals in Kwa Zulu (Zululand) gives ample time to ponder on how "the old order changeth." Once admired efficient hospitals, many founded by and with a notable contribution from the British, are now understaffed and battling for survival. It is fair to contend that this is South Africa's problem. In fact, despite the exodus of doctors, most of the doctors are South African, helped by some Canadians and Germans. It is the paucity of British that hurts. A notable exception has been some dedicated students but even this is likely to cease if a total medical boycott, which is the objective of the UK Medical Students International Committee, is enforced.

Only those who have never been down into the valley of the shadow could take to themselves the right of denying life to people and that the end justifies the means: that sanctions and a medical boycott with consequential deaths will abolish apartheid and improve the health and welfare of the blacks.

If apartheid is the major cause of black ill health how is it that the Indian community of about one million, many of whom came to South Africa as indentured "coolie" labour and who suffer all the indignities and disadvantages of apartheid, are now a wealthy community with a lower infant mortality rate than that of people from Pakistan in the United Kingdom? In Cape Town the infant mortality rate of "coloureds" is almost at parity with that of whites, while in Soweto the infant mortality rate of blacks has dropped from 232 in 1950 to 35 in 1979 . While these are localised areas they are also those where the restrictions and injustices of apartheid are most deeply felt and bitterly resented. Nutrition is dominantly determined by economics, which sanctions will worsen; by education, which boycotts will worsen; and by family planning, an unAfrican concept.

While I accept students' idealism and understandable abomination of apartheid, they do not justify lack of factual information like maintaining that students coming to hospitals do nothing to help; or biased claims that the cultural gap is too wide to be bridged by white United Kingdom students (what have missionaries achieved?), or ignoring the importance of infant mortality rate and the history of treatment of Indians in other areas by "democratically" elected African governments. What is unacceptable is that the Hippocratic Oath-that my first concern is the welfare of my patient-is to be replaced by: my first concern shall be the politics of a country. The one factor that has placed medicine apart from and virtually above all other professions and commands the respect of all communities no longer holds, and medical values are comparable with those of West Indian cricketers, who believe that all things South African are untouchable even if some mitigation can be expected if public villification is expressed.

To maintain that this is just student behaviour no longer holds. Student protest coupled with the pusillanimous policy of the university authorities ensured the withdrawal of the medical faculty of 